\title{
LOOKING FOR MELAYU: TRANSLATORS AND SEAFARERS
}

\author{
Corazon D. Villareal \\ University of the Philippines, Diliman \\ cdvpanay7@gmail.com
}

\begin{abstract}
This essay explores literary relations between the Philippines and Malaysia through a study of translational exchange between the two countries. It argues that translational exchange between the Philippines and Malaysia cannot be understood only through a study of contemporary translations since the connections between the two countries date back to pre-colonial times. Other than a discussion of some contemporary translations, the article cites two cases of translational exchange. The first is Pigafetta's account of Enrique, the Malay slave/translator who accompanied Magellan in his expedition to the Philippines, and the appropriation of this account by a Malaysian historical novelist. The other case is the translations of Badjau-Sama tales. The link to the shared past between the Philippines and Malaysia in pre-modern times is Melayu, a cultural complex that can be understood partly through a study of common stories and tales that have that have undulated in the borderless seas of south of the Philippines and Sabah. We cannot just translate Malaysia as if it were apart from or foreign to us since there are components in our culture that connect inextricably with Melayu. In a sense, we translate Malaysia as we translate ourselves.
\end{abstract}

\section{Keywords}

Translating Malaysia, Southeast Asian translation, Philippine-Malaysian translations, Melayu, translating Badjau

\begin{abstract}
About the Author
Corazon D. Villareal is Professor at the Department of English and Comparative Literature, University of the Philippines, Diliman of which she was former chair. Her main publications are on translation and translational processes relating to Philippine literature and culture, among them, Translating the Sugilanon: Reframing the Sign (U of the Philippines P, 1994) and Siday (Ateneo de Manila UP, 1997). Her international publications have appeared in the Asiatic (2010), Language Teaching (2012), and The Global Local Interface: Language Choice and Hybridity (forthcoming). She was recipient of a Fulbright Senior Research Fellowship at Columbia University in 2006 and was an international associate at the Translation Workshop of the Nida School of Translation Studies in Misano, Italy in 2011.
\end{abstract}


THIS ESSAY EXPLORES LITERARY RELATIONS between the Philippines and Malaysia through a study of translational exchange between the two countries. It argues that in translating Malaysia, the Filipino translator has to situate the translation in a larger, earlier context such as Melayu. The term "Melayu" resonates with the paradox of the Filipino's kinship with the Malay and distance from it (malayo in Tagalog; malayu in Hiligaynon). But translation can be a strategy to negotiate this paradox.

In attempting to reconcile this paradox, the essay first takes into account a number of Malaysian literary works translated into Filipino from English under translation projects undertaken in the 1980s. But these mainstream publications can offer only a limited view of translational exchange between the two countries. Some "peripheral" texts may yield additional insights into the paradox since they reveal a shared memory between the two countries and a common drive to invent an identity beyond the colonial gaze. These are, in fact, two running themes in the essay. In developing these themes, some implications are also drawn regarding the nature of translation especially within the intra-regional dynamics of Southeast Asia. The "peripheral" texts are sourced from sea-related folklore shared by the two countries, specifically, the cases of Enrique, Magellan's Malay slave, and the Badjaus. The perspective, however, shall be that of a Filipino trying to reconnect with Southeast Asian cultures.

The term "translation" would refer to "real" translations between cultures and different semiotic systems (as classified by Roman Jakobson in 1959), but here, it shall be taken broadly as cultural translation-in the sense that Clifford in Writing Culture (1986) and Routes (1997) used it to describe developing and multiple identities in travel and border crossings. Translation always already implies a crossing, and for this reason, translation already involves translational exchange.

\section{Translating Malaysian Literature in the Philippines}

Our access in the Philippines to translations of Malaysian literature has been limited; most of these are translations into English found in the few academic productions on Malaysian literature (please see, for instance, Hernandez, Yaapar, and Saman). However, except for Yaapar's translations of some Malay folk literature into English, translations of Malay literature in these theses have been taken from existing studies, which are predominantly British (please see, for instance, Winstedt).

There was hardly any Southeast Asian work translated by Filipinos (see, for example, Antonio). Such initiatives came only in the 1980s, from the Councils of Information (COCI) of ASEAN member countries and the Toyota Foundation. The latter sponsored the translation of works from Japanese and other SEAsian countries into Filipino while COCI commissioned the translation of Southeast Asian works from their original languages into the national language of each 
country and into English, this being recognized as the lingua franca in the region. But these institutional moves were short-lived. The translation program of COCI was discontinued due to other funding priorities, and the Toyota Foundation terminated the program as soon as it perceived the Southeast Asians were already talking to each other, ensuring a cohesive market for Japanese goods (Sionil Jose, qtd. in Tope, "Translating Southeast Asia").

However, the programs were an opportunity for the Filipinos and the other ASEAN peoples to translate back, so to speak. The translators found an opening to construct and reconstruct their literatures and cultures. The translation project, moreover, was viewed as a means to strengthen solidarity. As Anacleta Encarnacion notes in her translation of Modern Stories from Malaysia into Mga Makabagong Kuwento Mula Malaysia:

...ang paksa ay buhay ng tao, sinumang makakabasa ng mga kuwentong ito ay di maaring sumangayon sa mga pangyayari rito, kahit tubong Europa, America, o Africa. At lalo siyang sasangayon kung siya'y tulad kong taga Asia... pangkahalatang tema ng karalitaan, pag-ibig, pulitika, intriga sa lipunan, kamatayan, atbp. (6)

... the subject is life; whoever reads these cannot but identify with the events here, whether the reader comes from Europe, America, or Africa. And more so, if the reader comes from Asia like me... familiar with the themes of poverty, love, politics, social intrigues, death, etc. [English translation mine]

For example, the theme of extreme poverty and the inability to control forces larger than life is developed in Anwar Ridhwan's "Jambu, Anak ni Sungai" (Encarnacion's translation of "Jambu, Son of the River"). Jambu, newly married and father to a few-weeks-old baby, works part-time for a rubber tree plantation. However, because of the drop in the market price of rubber, he is unable to earn enough even for food. He attempts to catch fish in the river, but with the heavy rains and the rushing waters of the river, he cannot even catch a single fish. For the survival of his family and the future of his son, he is forced to make a difficult decision that causes deep sorrow to his young wife: sell his baby to an arrogant and rich man and his wife who have long been childless.

In Shanon Ahmad's "Naipit sa Gitna” (Encarnacion's translation of "Caught in Between"), the theme of conflict between tradition and modernity is explored. Here, a village couple cannot reconcile with their son for whom they worked very hard to send to the United Kingdom for education. The reason is that he marries a European woman and lives in the city. Since the young couple is childless, the father suggests as condition for reconciliation his son's taking a Malay as a second wife. But even this, the son refuses. 
Meanwhile, "Ang Regalo" (translated by Encarnacion from Arena Wati's “The Gift") is about the struggle to uphold Islamic values in the face of temptations of the modern world. Munji turns 40 and for the first time celebrates with a party. His friends are rowdy; they are disappointed that no alcohol is served, and one friend even gives Munji a gift of a baby pacifier and candies (a joking reminder of a past transgression of Munji). The high point of the party, however, is the gift that Munji's parents send him; curiosity turns to shock when his daughter opens the gift-two gravestones with this inscription: “...Sa malao;t madali/ Ito'y gagamitin mo./Sana'y nagingat ka sa tukso ng mundo" (100). ("Sooner or later, you will use these/ So be careful/ Do not fall into the temptations of the world.").

In the foreword to Krisis, his Filipino translation of Crisis, Barclay Newman's English translation of Alias Ali's novel in Bahasa Malay, also titled Krisis, Rogelio Sicat alludes to the paradox of Melayu: "Sa tagal ng ating pagkahiwalay at pagtanaw sa malayo, na ang kultura'y pilit pa nating pinaparisan, nakalimutan nating tumingin sa ating kapitbahay" (5). (Long separated [from the Malay] and setting our sights on a distant culture [Western] we have wanted to imitate, we forgot to take a look at our neighbor) [English translation mine].

In fact, except for some obvious differences like names of people and places, the personal and social predicaments these Malaysian characters face are like the Filipinos.' These are similarities that the translator, Rogelio Sicat, is conscious of, and his translation in Filipino gives the readers a feel not just of Malay but of Filipino. Krisis, for instance, revolves around Jabar. In his thirties, Jabar is poor, unemployed, unmarried, but idealistic. He challenges a rich and corrupt candidate of a ruling political party in a Malaysian barrio. Eventually he wins the contested seat for the local legislative assembly with the support of his fellow common people who use home-grown campaign tactics and local camaraderie to dislodge the incumbent. It is apparent that Jabar and his friends hold a somewhat naïve faith in democracy as a panacea for their problems but this pays off in the end with his victory. It must be noted that Krisis was published in 1966-Malaysia was at the threshold of independence and full of hopes for a better life. Although it is unlikely that a man with no means like Jabar can challenge ruling politicians and dynasties in the Philippines today, in the pre-dictatorship era in the 196os, someone could have done a Jabar.

Moreover, certain scenes could have happened in the Philippines, as the following excerpt shows:

Uhaw ang Pekan Bara. Sa loob ng dalawang mahabang linggo'y di umuulan. Makikita sa lahat ng dako ang palatandaan ng tagtuyot, Ang damo sa magkabilang gilid ng ng kalsada'y natatakpan ng madilaw na alikabok (11). Pekan Beka is thirsty. For two long weeks, it has not rained. Signs of the dry spell are everywhere. The grass on both sides of the street is coated with yellow dust.. 
In the next excerpt the hunger that the character experiences may be familiar to a Filipino laborer:

Ang init! Para kang nasa impiyerno. At bukod pa rito, nagugutom siya. At nauuhaw pa. Ang gusto niya ngayo'y isang plato ng mainit na kanin at isang baso ng tubig na may yelo. (12).

So hot! It's like hell! Aside from this, he is hungry. And thirsty. What he wants at this very moment is a plate of steaming rice and a glass of water with ice.

In the foreword to Muling Lumipad ang Kalapating Puti, Domingo Landicho's Filipino translation of The White Dove Flies Again, Harry Aveling's English translation of Khadijah Hashim's novel in Bahasa Malay titled Merpati Puti Terbang Lagi (1972), Landicho makes an observation similar to Sicat's:

Bagama't ang pangyayari'y naganap sa Malaysia, and diwa ng nobela'y parang isang karanasang mula sa lipunang Filipino ... hinggil sa nayon at sa mga pangkaraniwang tao (5).

Although the events happened in Malaysia, the theme of the novel relates to an experience drawn from Filipino society... about the barrio and the common people. [English translation mine]

The characters in Muling Lumipad, like Krisis, come from a poor Malaysian village, and the the novel focuses on the mass action of farmers to possess the land they till. The Malaysian farmers in Hashim's novel have to contend with natural calamities, are deep in debts, suffer from hunger and lack of education, and most of all, contend with government officials who turn a deaf ear to their needs. The farmers, however, find a champion in Farid, an ordinary government employee, who, along with some friends, tries to make representations with the local government offices on behalf of the poor. They do not succeed, but they have sufficiently organized themselves to launch Farid's candidacy for a local post. The story ends with Farid's resolve: "Hindi ko sila bibiguin." (250). (I will not fail them.) It appears then that for both Krisis and Muling Lumipad ang Kalapating Puti, the option for alleviating poverty and fighting corruption remains to be the democratic process.

\section{Connecting with Melayu}

From the forewords of the three translations and their synopses, it is clear that the translators chose the works for what they could show about social realities in the Philippines and Malaysia in the second half of the 2oth century. Although both Encarnacion and Sicat refer to past connections between the Philippines and Asia, the stories they translate actually deal only with contemporary realities. 
Building our connections with Malaysia from these initiatives is restrictive since most translations were based on written literature produced in the 2oth century and marked by modern boundaries of nation. The implicit assumption is that the Philippines and Malaysia, being modern nation-states, are distinct from each other although parallels exist in their economic, social and cultural realities.

This unity though cannot be founded solely on observed similarities. Such a view truncates the past connections of the Philippines to Malaysia and the larger culture to which they belong. The matter is of crucial importance to the Filipino establishing Southeast Asian links, for despite the comforting grace of antiessentialism, the Filipino is still considered more Western than Asian. Therefore, the object of translation should not just be modern Malaysia but Malaysia in her larger historical context and geographical reach. The Filipino translator seeking to bridge the cultural distance between the Philippines and Malaysia should be concerned not only with the translation of Malaysia (which was created only in 1967) but Melayu. This task would entail looking back to earlier and non-mainstream accounts. Here seafarers are central figures-the maritime being the link among Malay speakers and other Southeast Asians (please see fig. 1 [Hayase 17]).

Today, Melayu/Malay is considered the core culture of Malaysia (as well as that of Indonesia and Brunei). Melayu, according to Reid, is based historically in Malayness, a cultural complex centered in the language called Melayu.To him, this is "the language all chose as their national language (though developed in different standards, with different

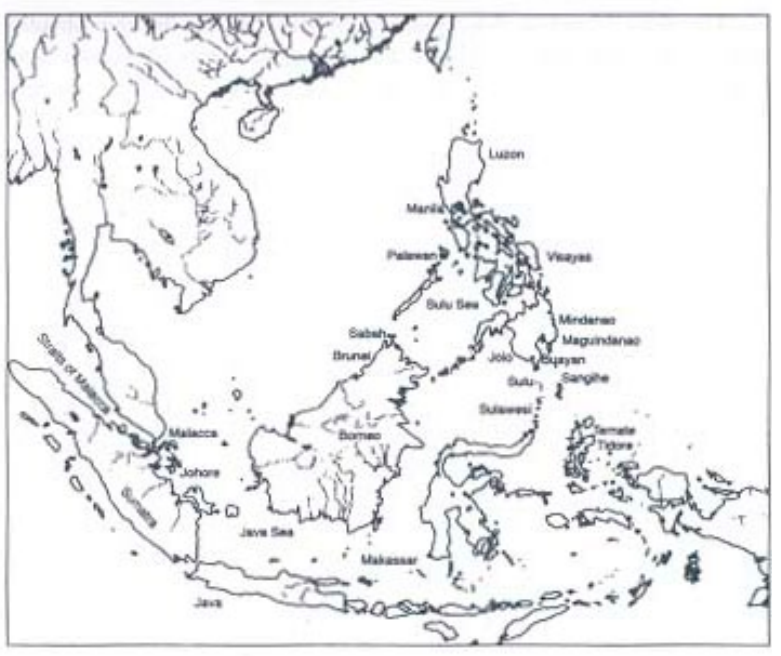

Fig. 1: Map of Maritime Southeast Asia patterns of modern borrowings from English, Dutch, Javanese, Sanskrit and Arabic)."

Salazar and Mojares reiterate that Rizal (as well as other propagandists like Trinidad Pardo de Tavera, Pedro Paterno, and Isabelo de los Reyes, and European friends such as Ferdinand Blumentritt) invoked this Melayu connection when faced with the accusation that the Filipinos did not have a civilization prior to the coming of the Spaniards. Rizal, in "The Indolence of the Filipinos," reacting specifically to Barantes, points out that as the Spanish missionary chronicles show, the Malayan 
Filipinos carried on an active trade, not only among themselves but also among the neighboring countries. In his edition of Morga, who identified the people of Manila and its surroundings as "naturales Malayos," Rizal notes that the ancient traditions that connected the Filipinos to Sumatra were lost as a result of the friars' zeal to extirpate "all national memory"(qtd. in Salazar 117). Filipino nationalists in the early American era, such as Wenceslao Vinzons from the University of the Philippines, also cite this Melayu connection when, like the Spanish colonizers, Americans propagated a discourse on the primitive Filipino.

It is interesting to note that this awareness of Melayu Raya or a greater Malay identity was not exclusive to Rizal and other Filipino nationalists. The idea was concurrent with that of Indonesian leftists such as Mas Marco, Tirto Adi Soerjo, and Tan Malaka who envisaged a Pan-Malay region consisting of the Philippines, Malaya, and Indonesia whose people spoke Malay languages (Talif and Marasidi 19). Similarly, in the early decades of the 2oth century, teacher-trainees at the Sultan Idris Teachers' College in Malaya spread the concept of a Melayu Raya among the students through journalistic articles, stories and novels. Such orientation on Malay nationalism is seen in novels of this period: Jakah Salma (1928) by Abdul Rashid Talu, Melur (1930) by Harun Aminurashid, and Percintaan Kasih Kemudaan (1927) by Ahmad Bin Kotot (Talif and Marasidi 20).

But complications arise in looking for Melayu and translating it. It soon becomes apparent that it is an elusive object for translation. For one, Melayu refers to a geographical spread dating back to pre-history. Bellwood writes that in the context of the whole Southeast Asian and the Australasian region, Melayu refers to the Indo-Malaysian Archipelago, whose indigenous peoples (with restricted exceptions in the Malay peninsula and the far east of Indonesia) belong to the same major Austronesian-speaking ethnolinguistic group (105). Melayu thus cannot be confined to the Malaysia of today (the Malay peninsula, Sabah, and Sarawak) because it also covers modern Indonesia and surrounding islands.

Moreover, the meaning or referents of Melayu have evolved, depending on who constructed it. In the second-century CE, the Egyptian geographer, Ptolemy first used the term Melayu Kulon to refer to the area south of Burma, while the 12thcentury Arab geographer Edrisi reported "Malai" as a large island off southern Asia full of gold, spices, elephants and rhinoceros (cited in Reid 8). In Chinese records, beginning with Yijing in the seventh century, "Malayu" appears as a more specific kingdom to the north of Srivijaya, absorbed into the latter in the 68os AD. The Dutch and British had their respective translations of Melayu.

Filipino perspectives of the Malay world are multi-layered: these are filtered through Spanish accounts of expeditions to Borneo, Jolo, and Mindanao, such as that of Pigafetta, who interpreted translations by unnamed native informants; in turn these were translated into English by Blair and Robertson. Citing Colin's Labor Evangelica, Madrid 1663 writes of "Moro Malays from Borney,... an island near the 
mainland of Malacca where there is a district called Malayo," which was considered the "original homeland" of all the Malays (trans. in Blair and Robertson 38).

It is tempting thus to adopt an Orientalist view when speaking of translations involving Malay or to assert the usual dichotomy of East and West. To translate "Melayu" had been a way to "conquer" Melayu.

\section{Re-viewing Philippine-Malaysian Translational Exchange}

Melayu or Malayness in post-independent Malaysia is continually being reimagined. As Nietszche says, "value and perspective change with the individual or the nation that is looking back into the past." According to the Malaysian Constitution, a Malay is one "who professes the religion of Islam, habitually speaks the Malay language, [and] conforms to Malay customs." The Malays are the largest of three officially recognized bumiputera (sons of the soil) or indigenous groups in Malaysia. However, certain developments such as the ethnic riots in 1969, the resurgence of Islam in the early 1980s, and the growing Malaysian economy have necessitated re-workings in the meaning of Melayu (Goh Beng Lan 184-216). With regard to literature, this multiplicity has resulted in some disjunctures; in the case of contemporary Malaysian stories, Shirley Geok-lin Lim and Wong Soak Koon write that these stories "take a profound resonance in the context of instabilities set up by the incongruous convergence of Malay, Indian, Chinese, and European cultures, and an encroaching secular and material culture" (qtd. in Yamada 194).

For a Filipino translator seeking to connect with Malaysia, the question is not "what is Malaysia" or what works constitute Malaysia, since Malaysia is enmeshed in Melayu, which historically has been in flux. Moreover, Malaysia within the context of Melayu is a hybrid that cannot be confined within the boundaries of the nation that she is today. In a sense, the seductive lure of Benjamin's concept of the "afterlife" fades as the prior life of the translation object is examined. Thus, the Filipino translator's project is not so much to look for equivalence between cultural objects of the Source (Malaysia) and the Target (Filipino). The concerns for equivalence and faithfulness become secondary; the significance of issues of domestication and foreignization as distinguished by Venuti is diminished. The locus shifts from the object of translation to that which transpires between the source and target, or that which transpires between the Filipino and the Malay.

In the foreword to Hernandez's thesis, Eugenio writes: "We should explore the relations of Philippine culture not only with Malay culture but also with other Southeast Asian cultures if we are to fully understand our own." But the inverse may also be true. We need to translate not just Malaysia or even Melayu but the components in our culture that connect inextricably with Malaysia and Melayu. In a sense, we translate Malaysia as we translate ourselves. Relationally constructed, translation deals with the shifting identities of Melayu in which both the Filipino 
and the Malaysian are agents. Such translations are different from constructions in travel and missionary accounts in which "the translator" is an outsider looking in, from the vantage point of superiority, even as the identity of the real translator is concealed quite conveniently in the term "informant."

At this juncture, it should be pointed out that the Malay term for literature is sastera which according to Teuw (qtd. in Salleh 18) originates from Sanskrit roots: sas means "direction, teaching, and instruction" while - tra means "instrument and suggestion." Originally thus, sastera referred to "a tool for teaching, a guide book, a book of instruction." Salleh points out that in early Malay literature (as in early English), literature or sas included laws, political documents, and social criticism." Another Malay word of currency for literature is pustaka which originally meant "a book of magic." Still another Malay word for literature is persuratan, coming from the root surat, which means "to write," thus referring to written materials; this use, however, is recent. It is closer in meaning to the Filipino word for literature-panitikan, formed from the root word, "titik" or letter, and the English word "literature" which comes from the Greek litera, meaning "letter" or "writing." It is important to keep this range of meanings in mind in tracking translational exchange with Melayu since the texts translated or culturally transmitted are not just confined to contemporary written texts, but to historical and mythical accounts which sastera or pustaka encompass.

Two cases of such sastera have been selected from points in the continuum of Melayu. These are the accounts on Enrique, Magellan's Malay slave cum translator, who sailed with him in the expedition that arrived in Mactan in 1521, and translations of Badjau tales that have circulated from ancient times. These might appear to be accounts too diachronically apart, but they are pre-modern and early modern texts lodged in the present. Thus, they are sites of translational contact between the Philippines and Malaysia within Melayu, within whose wider frame PhilippineMalaysian translational exchange should be sited.

\section{Enrique's Translated Lives}

Although Enrique, Magellan's Malay slave, was born in Sumatra, his life moved in the interstices of Malaysia and the Philippines. His case demonstrates how an imaginative translator/writer seizes the initiative in elevating a Malay translator silenced in colonial accounts of the Philippines.

In historical accounts on the travels of Magellan from Spain to the east in search of spices, which eventually brought them in 1521 to Cebu (located in Central Philippines), chroniclers in Magellan's expedition mention a Malay slave sold to him by Alfonso, who was a leader of the Portuguese forces that had conquered Malacca. The slave was baptized and assumed the Christian name of Enrique. Pigafetta says that he was from Zamatra (Sumatra), and in Cebu, he spoke to the people in a language they could understand. 
Enrique is considered a peripheral character in Philippine history. The principal actors in Spanish colonial accounts were Magellan and Lapulapu, the datu or chieftain from Mactan, Cebu who had killed Magellan in a battle. From the colonizers' eyes, Lapulapu had delayed Spanish colonization of the islands up until the coming of Legazpi in 1563. However, viewed from post-colonial lenses, Lapulapu was the first Filipino, having successfully challenged encroaching Westerners (although the claim is in itself contentious since at that time there was no Filipino nation to speak of).

In Pigafetta's account, nothing is mentioned of Enrique after Rajah Humabon of Cebu had slain about 27 of Magellan's men who survived the battle of Mactan. With his eye on jewelry and other booties in the Spanish galleon, Humabon had invited them to a drinking party and when they were too drunk to fight, he had them killed. It is not clear whether Enrique was among those killed. But the marginal translator is transformed into a heroic character by a Malaysian novelist, Harun Aminurrashid. Harun uses this material for his novels Panglima Awang (Awang the Warrior) and Anak Panglima Awang (The Son of Awang the Warrior) although literally, panglima means "commander."

Both Portuguese and Malay reports attest that the defeated Malays sustained attacks on the Portuguese in Malacca for decades after its conquest. Harun casts Awang as a key figure in this struggle. Using these reports as bases, he builds a realistic character-selfless and dauntless, religious but human-and raises him "to the level of a symbol of Malay ideals of independence, integrity, and courage" (Salleh 62). In Panglima Awang, young Malay readers are brought into contact with a glorious past shaped by heroes who fought for their land and rights.

Enrique is an unlikely link between the Philippines and Malaysia, but his marginalization in European accounts and the silence in Philippine history books is one index of how we have traditionally viewed such relations. However, the case of the nondescript slave/translator transformed into the heroic Awang through the novelist cum translator shows how a non-mainstream account can be invested with a cultural meaning of value to a people and how, in a sense then, historical vignettes may be considered sastera in which, more signifcantly, the central figures are Malay, and not Western. Unfortunately, the Filipino reader can access Harun's novel only through a secondary source. The work is waiting to be translated into Filipino and so is Enrique waiting for yet another life.

\section{The Badjau Connection: Translating Melayu}

The case of Enrique has demonstrated the empowering potentials of translational exchange between the Philippines and Malaysia. But it would also be interesting to see if a similar empowering result comes from the translation of Melayu within us. In this regard, the easy path would be to look into the mainstream, or connections with Melayu through translations circulating among the three most dominant 
Islamic ethnic groups in Mindanao-the Tausug of Sulu, the Maranao of Lanao, and the Maguindanao of Cotabato (although their populations have spread out to other areas in Mindanao, Metro Manila, and other parts of the country). As Majul remarks, "Islam's advent in the Philippines [is] a function of the general expansion of Islam in Malaysia" (39). Following Majul's lead, the translator/scholar should explore, among others, religious texts which through the sufis, were transmitted, translated, and localized among the peoples in the Melayu world; the lexicography of trade, business, and material culture in Malay that have found their way into Tagalog, Visayan, and ethnic groups in Mindanao; and tarsilas, the genealogical accounts of sultanates that trace their Malay roots.

However, this study directs its angle of vision toward an ethnic group in whom the continuity of our Malay connections seems marked, but whose survival is now threatened by various forces. These are the Badjaus. The Badjaus were widely distributed in East Maritime Southeast Asia in the period of Islamization in the 15th century and in the Age of Commerce in the 16th-17th centuries. East Maritime Southeast Asia included the Sultanates of Brunei, Sulu, Ternate-Tidore, Makassar and Maguindanao. Sea-faring peoples did not form sultanates but provided them support-the Illanuns and the Samals provided shipping and naval power (as pirates) while the Badjaus provided marine products and information. The distribution of the Badjaus was almost identical to the whole maritime world (Hayase 18). Today, they belong to a much larger group of Sama-Badjau speakers who are considered the most widely-spread ethnolinguistic group in Southeast Asia. ${ }^{1}$ The autonym of the Badjaus is Sama, and in Tawi-tawi in Zamboanga and in eastern Sabah (Sather 6,) where most of them are now found, they are called Sama Dilaut (Sama of the Sea) to distinguish them from the shore-dwelling Samas. There is a large Sama Dilaut population in the Sibutu Islands in Sulu, of which Sitangkai is the largest (Nimmo 29). The Sama Dilaut in Semporna in Sabah are closely related to the Sibutu people; in fact, many think of themselves as natives of Sibutu rather than Semporna (Nimmo 31). Many rich fishing reefs provide natural bridges between Sibutu and Semporna (Nimmo 31) (fig. 2 [Rixhon n.p])

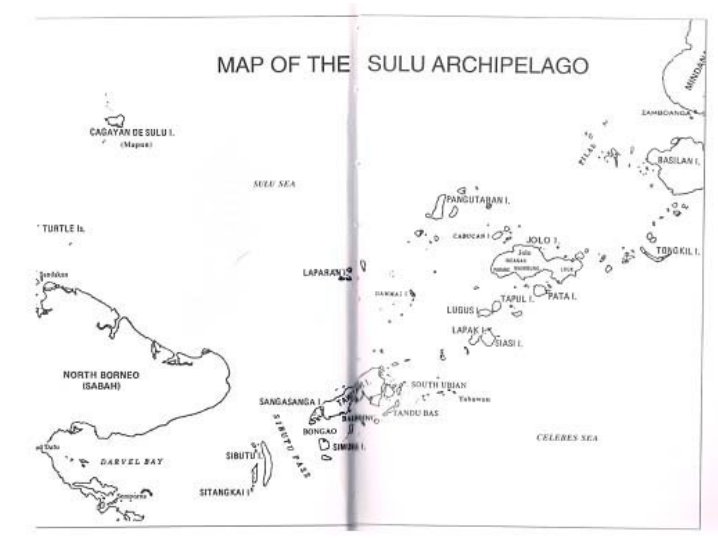

In Eastern Sabah, Badjau communities now live in stilts, particularly in the SempornaLahat Datu and Sandakan areas (Nimmo 31). Some of these coastal settlements serve as transit points for people who come and

Fig. 2: Map of the Sulu Archipelago(10), Carmen, Carmen (11), Jocelyn (9), Teresita (5), Jose, Jr. (4). 
go, including those traveling in the sea lanes between southern Philippines and Sabah without the use of travel documents (A Noor). Because of the proximity of these areas in the Philippines to Sabah, ${ }^{2}$ and the inevitable economic, cultural, and religious connections, Sama culture is a concrete site for relating with Malaysia.

Among the Badjaus in Tawi-tawi, Zamboanga, and Semporna in Sabah where Badjaus circulate in the borderless sea, translations and versions of the katakata, myths, proverbs, etc. have flowed from pre-Islamic through Islamic times, linking them to the wider Islamic world. These translations havegenerally escaped the notice of literary scholars and translators in the country.

An access point for the Filipino would be works by and on the Samas generated in Malaysia today. The anthology In the Shadows of the Palm (2009) includes translations into English of narratives by East Malaysian natives including the Badjaus, who, according to Wong Soak Koon, are also part of the bumiputera"sons of the soil" or indigenous Malaysians. The works suggest our historical and linguistic links with the Samas. Among these works are Azmah Nordin's "Come to the Land beneath the Wind" (Datang ke Bumi Buwah Bayu) and Siti Hadiah Hj. Abd. Mutalib's "Daling-Daling." These are translated by Firuz-Zamri from Malay into English. Narrated from the point of view of Dayang Bandang, the first story is set in the 1900 s as the British are strengthening their hold on the indigenous Malay. One military strategy they use is to set off tribes against each other. Dayang's husband, Mat Salleh, resists these incursions but in deference to the Sultan of Sulu (beholden to the British who supported him in the conflict with the Brunei sultanate), he agrees to hold peace talks with Cowrie, a British merchant. Cowrie traps him into signing a treaty that effectively bans him from returning to Inanam, the land he owns. Subsequently, English forces assisted by a Dayak infantry attack Salleh's forces, and eventually he dies in the Sulu oceans. Set in Malaysia today, "Daling-Daling" deals with the conflict between tradition and modernity. The female narrator laments her husband's preoccupation with corporate life and his lack of respect for her Badjau heritage.

The following excerpt from the lyrics of a Badjau song in Nordin's "Come to the Land beneath the Wind" shows linguistic similarities with some Philippine languages.

Mai daling-daling
Manuk-manukku pulah
(Mai daling-daling
My birds are red)
Okatn ku hu lara
Bang umabut lisag dua
Mai daling-daling

Kritika Kultura 21/22 (2013/2014): -298

(c) Ateneo de Manila University

<http://kritikakultura.ateneo.net> 
(Upon the pepper tree I tie

If at two o'clock he arrives

Intending to come the day after). (148)

[English translations from the source text.]

In Tagalog, the word for chicken is "manok," while "red" is "pula;" in Hiligaynon Visayan, "two" is "dua," and " to arrive" is "abut."

In the Philippines, studies on the Sama and translations of Sama orality have come mainly from foreign anthropologists who did their field work on the Badjaus mostly in the 1960s through the '70s (Sopher; Sather; Pallessen). ${ }^{3}$ Studies and translations specific to the Badjaus in southern Philippines have come from anthropologists Nimmo, Rixhon, and Revel, who have worked with Samas like Talib Lim Sangogot and Sama singers to record and translate tales. Mainly, these are the katakata, epics considered as sacred literature, and the kissa, or sung narratives. Synopses and excerpts in English translation are included in Tali Lim Sangogot's "The Tawi-Tawi Sama Voice" (Revel 59-73). Some of these narratives are now stored in the archives of Ateneo de Manila University.

Linguistic evidence points to the Indonesian origins of the Samas who are believed to have settled in the Sulu Archipelago more than a thousand years ago. (Rixhon, qtd. in Revel 26). To look at Sama-Badjau culture in southern Mindanao would be to follow literary currents that have flowed from pre-Islamic to Islamic times, merging into the stream of myths, epics, and proverbs of the Philippines and Malaysia today, and linking these, moreover, to the wider Islamic world.

The links are concrete. An example of a narrative circulating among the Badjaus is the Mi'Raj story that narrates the prophet Muhammad's ascension into heaven (in Arabic, "Mi'raj" means "ladder). "[The] longest and most elaborate chanted texts are those of the Persian and South Indian Muslim sufis that in turn influenced the Mi"Raj stories of Malaysia, Indonesia and the Philippines" (Rixhon 36). The Mi'Raj links us then to the Arab world, but more significantly in the context of this study, to dunia Melayu. A synopsis as well as some excerpts in English translation can be found in Rixhon's "Journey into Sama Literature" (Revel 23-58).

Malay links are also evident in Sama Dilaut origin myths that date back to preIslamic times. Origin myths were collected in Sitangkai by Nimmo, but many versions are found among the Tawi Tawi Sama Dilaut. The basic story, according to Nimmo, is that the ancestors of the Sama Dilaut live in Johore with houseboats as dwellings. One day, a strong wind blows through Johore. To secure the houseboats, the village headman sticks a pole into the sea floor, and the other villagers tie their houseboats to that of the headman's. As it turns out, however, the pole does not stick into the seafloor but into the back of a giant stingray. So the villagers find themselves afloat in the open sea for a week, until the headman pleads for help from Tuhan (Malay for Lord). Tuhan sends a saitan, a spirit, who then enters into the headman who then becomes the first djinn among the Sama Dilaut. The saitan 
instructs the headman to sail toward the East and after two days, the villagers reach shore where they stick a pole (called samboang in Sinama) into the seafloor. This is their first port in the Philippines, a place we now call Zamboanga. The Malay links of the Badjaus are evident even in the tarsilas of the Maguindanao sultanate. These narrate how Sharif Kabungsuwan, after the fall of Malacca to the Portuguese, has left Johore and arrives on the shores of Mindanao assisted by sea-faring followers, the Samals. Kabungsuwan is actually the son of an Arab from Mecca who settles in Johore where he marries the daughter of a Malaccan sultan (Saleeby, qtd. in Majul 23-24). The fall of Malacca resulted in the dispersion of the old Malacca royal family with their followers; it is believed that the seafaring Samas facilitated this dispersion (Sopher, qtd. in Majul 24).

\section{Bridging, Disconnecting}

The enterprise of translating the Badjau has allowed us to transit in space and time to understand how Melayu runs deep in the Filipino. The other attraction, as yet unarticulated, is the vision of the creative resistance of a diaspora that for centuries has navigated within and around dominant Malay groups while keeping its identity distinct. But the vision fades with lamentations over a people besieged by forces they have not been able to understand, much less withstand.

The sea-based trading network in Melayu, once controlled by sultanates and port centers, had been overtaken by a capitalist trade system dominated by the colonial powers. Whereas the Badjaus excelled in their seafaring skills and shipbuilding ability, they then found themselves eased out of the sea lanes during the colonial era and in the advent of sophisticated maritime technology. To quote Abinales, "the entrenchment of various colonial boundaries and the growth of the customs and immigration agencies of the colonial states... reinforced this displacement of the SEASian network by world capitalism. Moreover, the new colonial map meant a different notion of boundaries as well as rules of access and passage" (50-51).

In the Sulu area, the Badjaus are considered by the dominant Tausugs as luwaan (luwa means literally to spit out): they are the lowest in the ethnic hierarchy. From the closing decades of the last century, changes have been both drastic and violent to the generally gentle and tolerant Badjaus. In the Martial Law period (1973-1987), many were shot by the military and others were displaced by aggressive outsiders taking advantage of the trade boom in agar agar (red seaweed used for gelatin and other culinary purposes) that grew best on the reefs where most Badjaus lived (Nimmo 235). In recent years, because of continuing strife between the government and rebel forces, lack of opportunities, poverty, and government neglect, many Badjaus have migrated to urban centers north of Manila such as Angeles City, Dagupan, Baguio, where women and children have resorted to begging. Some families have settled by railroad tracks south of Manila in Binan, Laguna, where they live together in wall-less abodes similar to their boathouses, the lepa, while 
earning a living peddling miscellaneous items. Still others have gone to Sabah and Brunei to work under better conditions. The last census in 1987 estimated the Badjau population in the Philippines to be 30,000 , but the exact number today is unknown. Probably the oldest among the ethnic groups in the south, one of the last to be Islamized, the Sama Badjau - with their shipbuilding technology, the $u k k i l$ or carving art, songs and dance, etc.- - is a vanishing culture. ${ }^{4}$

Research on translational exchange between the Philippines and Malaysia has allowed us to see our kinship in two ways. As the translators Encarnacion, Sicat, and Landicho observe in their Filipino translations of Malaysian works, Filipinos and Malaysians share parallel concerns. However, these translated works deal only with modern Malaysia and do not go far back into the historical connections of the two countries. It is for this reason that we need to look at translational exchange in the context of Melayu. This essay has demonstrated the redemptive power of translation in the case of Enrique and has revealed a shared memory through Sama narratives undulating in various translations aming the Samas in the borderless seas of the Sulu oceans and Eastern Malaysia, and now in the archives of Manila. These are evidence of what Farish A. Noor refers to as the "shared, overlapping histories of the many diasporas that populate this complex and sometimes confounding archipelago [referring to SEAsia]...." (page number?) Thus, the idea of translating Malaysia by translating ourselves is not narcissistic but inevitable. And that translation itself, as Gentzler writes, is "less something that happens between separate and distinct cultures and more something that is constitutive of these cultures" (qtd. in Arduini and Neergard 12),

In a sense, the paradox has been demystified. But the study has opened up as well the realities that divide. Is translation the answer? 


\section{Notes}

1. Both sea-nomadic and settled Badjaus are dispersed in a vast maritime area of 3.25 million square kilometers extending from east Palawan, Samar, and the seacoasts of Mindanao to the north, through the Sulu Archipelago, to the north and east coasts of Borneo going southward to the straits of Sulawesi, then toward scattered areas in east Indonesia (Sather 2).

2. With the formation of Malaysia in 1965, the east Malaysian states of Sabah and Sarawak were added to her territory. However, the Philippines has had claims on Sabah and the question has been an irritant in Philippine-Malaysian relations.

3. Early references to the Samas came from accounts by European travelers. In 1521, Pigafetta reported on some people in the vicinity of present-day Zamboanga as "making their dwellings in boats and do not live otherwise" (Pigafetta, qtd. in Robertson 53). In 1667, Combes described a people he called "Lutaos" (the name has not held, but in Visayan, this literally means "people who float") whom he described as sea-dwelling people who traded with land-based ones. In 1773 Thomas Forrest, a British explorer, noted the presence of boat-dwelling people close to Semporna today.

4. For an excellent video documentary on the displaced Badjaus and the loss of their rich cultural traditions, please watch Nannette Matilac's Memories of the Sea.

\section{Works Cited}

Arduini, Stefano and Nergaard, Siri. “Translation: A New Paradigm." Translation. Inaugural Issue, 2011.

Abinales, Patricio N. Orthodoxy and History in the Muslim-Mindanao Narrative. Quezon City: Ateneo de Manila UP, 2010. Print.

Antonio, Lilia Francisco, comp. Apat na Siglo ng Pagsasalin (1593-1898). Quezon City: Sentro ng Wikang Pilipino, 1999. Print.

Ali, Alias. Krisis. Trans. Rogelio Sicat. Manila: Solidaridad, 1989. Print.

Barnard, Timothy P., ed. Contesting Malayness: Malay Identity Across Boundaries. Singapore: Singapore UP, 2004. Print.

Bellwood, Peter. Pre-history of the Indo-Malaysian Archipelago. Rev. ed. Honolulu: U of Hawaii P, 1997. Print.

Clifford, James and George Marcus. Writing Culture. The Poetics and Politics of Ethnography. Berkeley: U of California P. Print.

Encarnacion, Anacleta, trans. Mga Makabagong Kuwento Mula sa Malaysia. Manila: Solidaridad, 1989. Print.

Goh Beng Lan. "Rethinking Modernity: State, Ethnicity, and Class in the Forging of a Modern Urban Malaysia." Local Cultures and the "New Asia." Ed. C.J.W.L. Wee. Singapore: Institute of Southeast Asian Studies, 2003. Print.

Hashim, Khadijah. Muling Lumipad ang Kalapating Puti. Trans. Domingo Landicho. Manila: Solidaridad, 1989. Print. 
Hayase, Shinzo. Mindanao Ethnohistory Beyond Nations: Maguindanao, Sangir, and Bagobo Societies in East Maritime Southeast Asia. Quezon City: Ateneo de Manila UP, 2007. Print.

Hernandez, Flor Angel. "A Comparative Study of Representative Tagalog and Malay Poets 1950-1970." MA Thesis. U of the Philippines Diliman, 1977. Print.

Matilac, Nannette, et al., dir. Memories of the Sea: A Story of Sea Gypsies in the City. Produced by Nanette Matilac. 2006. DVD.

Majul, Cesar. Apolinario Mabini, Revolutionary. Manila: Vertex, 1964. Print.

Mojares, Resil B. Brains of the Nation: Pedro Paterno, T.H. Pardo de Tavera, Isabelo de los Reyes and the Production of Knowledge. Quezon City: Ateneo de Manila UP, 2006.

Nimmo, H. Arlo. Magosaha: An Ethnology of the Tawi-Tawi Sama Dilaut. Quezon City: Ateneo de Manila UP, 2001. Print.

Noor, Farish. "Between a fluid region and a hard state." Rappler: Thought Leaders. Rappler, 4 Mar. 2013. Web. 1o May 2013.

Nowell, Charles, ed. Magellan's Voyage around the World: Three Contemporary Accounts. Evanston: Northwestern UP, 1962. Print.

Pallesen, A. Kemp. Culture Contact and Language Convergence. Linguistic Society of the Philippines, 1985. Print.

Reid, Anthony. "Understanding Melayu as a Source of Diverse Modern Identities." Journal of Southeast Asian Studies (Oct. 2001): n.p. Web. 5 Oct. 2012.

Rixhon, Gerald, ed. and comp. Voices from Sulu. Quezon City: Ateneo de Manila UP, 2010. Print.

Robertson, James Alexander, ed. Magellan's Voyage Around the World. Cleveland: Clark, 1906. Print.

Revel, Nicole, ed. Literature of Voice. Epics in the Philippines. Quezon City: Office of the President, Ateneo de Manila U, 2005b. Print.

Salazar, Zeus. The Malayan Connection: Ang Pilipinas sa Dunia Melayu. Quezon City: Palimbagan ng Lahi, 1998. Print.

Saleeby, Najeeb M. Studies in Moro History, Law, and Religion. Manila: Bureau of Public Printing, 1905. Print.

Salleh, Muhammad Haji, comp. "Contemporary Malaysian Poems." N.p., n.d. Print.

--. "A Comparative Study of Malaysian and Philippine Folk Literature." MA Thesis. U of the Philippines Diliman, 1977. Print.

Saman, Mohd Sabian. A Comparative Study of Malaysian and Philippine War Novels. 1984. TS. Penerbiti U, Bangi.

Sather, Clifford. The Bajau Laut: Adaptation, History, and Fate in a Maritime Fishing Society of South-eastern Sabah. Kuala Lumpur: Oxford UP, 1997. Print.

Sopher, David E. The Sea Nomads: A Study of the Maritime Boat People. Singapore: National Museum 1977.

Talif, Rosli and Abdul Rahim Marasidi. "Charting Malay Literary Studies and Malay Self-identity." Reading the Malay World. Ed. Rick Hoking, Noritah Omar, et al. Australia: Wakefield, 2010. Print.

Tope, Lily Rose. "Translating Southeast Asia." "Towards an Indonesian Literary Translation Center" Seminar. British Centre for Literary Translation. Erasmus Taalcentrum, Jakarta, Indonesia. 8-12 Oct. 2012. Reading. 
Winstedt, Richard Olaf. Malay Proverbs. Singapore: Graham Brash, 1950. Print.

--. A History of Classical Malay Literature. Kuala Lumpur: Oxford UP, 1969. Print.

Wong Soak Koon, ed. In the Shadows of the Palm. Kuala Lumpur: Dewan Bahasa dan Pustaka, 2009. Print.

Yamada, Teri Shaffer. Modern Short Fiction of Southeast Asia. Michigan: Association for Asian Studies, 2009. Print. 